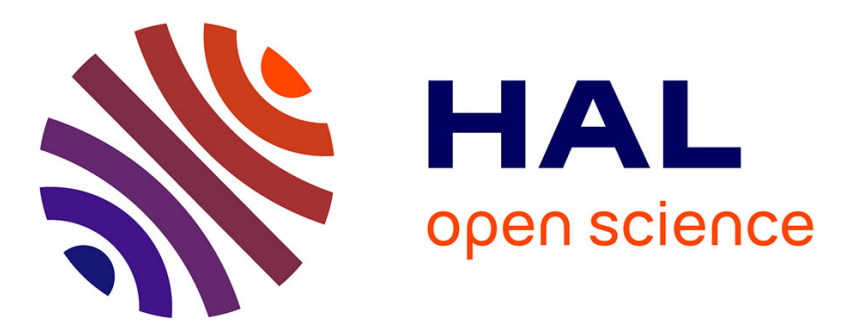

\title{
Ruthenium(II) and Iridium(III) complexes featuring NHC-Sulfonate chelate
}

A Rajaraman, A. R. Sahoo, F Hild, Cédric Fischmeister, M Achard, Christian Bruneau

\section{- To cite this version:}

A Rajaraman, A. R. Sahoo, F Hild, Cédric Fischmeister, M Achard, et al.. Ruthenium(II) and Iridium(III) complexes featuring NHC-Sulfonate chelate. Dalton Transactions, 2015, Dalton Transactions, 44 (40), pp.17467. 10.1039/C5DT02867A . hal-01223402

HAL Id: hal-01223402

https://hal-univ-rennes1.archives-ouvertes.fr/hal-01223402

Submitted on 2 Nov 2015

HAL is a multi-disciplinary open access archive for the deposit and dissemination of scientific research documents, whether they are published or not. The documents may come from teaching and research institutions in France or abroad, or from public or private research centers.
L'archive ouverte pluridisciplinaire HAL, est destinée au dépôt et à la diffusion de documents scientifiques de niveau recherche, publiés ou non, émanant des établissements d'enseignement et de recherche français ou étrangers, des laboratoires publics ou privés. 


\title{
Ruthenium(II) and Iridium(III) complexes featuring NHC-Sulfonate chelate
}

\author{
A. Rajaraman, ${ }^{a \S}$ A. R. Sahoo, ${ }^{a \S}$ F. Hild, ${ }^{a}$ C. Fischmeister, ${ }^{* a}$ M. Achard ${ }^{* a}$, C. Bruneau ${ }^{a}$
}

\begin{abstract}
Three new complexes bearing a chelating $\left(\kappa^{2} \mathrm{C}, 0\right) \mathrm{NHC}_{-} \mathrm{SO}_{3}$ ligand have been prepared. An original method for the synthesis of the imidazolium-sulfonate NHC precursor is described. The 5-membered ruthena- and irida-cycle containing complexes were fully characterized and evaluated in a series of catalytic transformations involving hydrogen auto-transfer processes.
\end{abstract}

Whatever their nature, ancillary or non-innocent multidentate ligands have significantly impacted homogeneous catalysis by enabling very efficient and selective transformations. Stunning examples may be found in stereoselective reductions, ${ }^{1}$ hydroformylations, ${ }^{2}$ carbonylations ${ }^{3}$ and other catalytic reactions. ${ }^{4}$ More recently, pincer ligands have also permitted major advances in a broad diversity of catalytic transformations. ${ }^{5}$ Our group investigated the potential of phosphine-sulfonate ligands $s^{6,7}$ in a number of catalytic transformations such as allylic activations, ${ }^{8} \mathrm{C}-\mathrm{H}$ bond functionalizations, ${ }^{9}$ hydrogenations ${ }^{10}$ including asymmetric hydrogenation of ketones and imines. ${ }^{11,12}$ Having in mind the tremendous impact of $\mathrm{N}$-Heterocyclic Carbenes (NHCs) in many catalytic transformations ${ }^{13}$ we became interested in the synthesis of metal complexes coordinated by chelating NHC-sulfonate ligands. Well-defined transition-metal catalysts bearing a chelating NHC ligand have already been described in a number of ways such as $\mathrm{NHC}-\mathrm{NHC},{ }^{14} \mathrm{NHC}$-oxazoline, ${ }^{15} \mathrm{NHC}$-alkyl. ${ }^{16}$ Bidentate $\mathrm{NHC}$ sulfonate ligands have only recently been reported in a very limited number of architectures. NHCarenesulfonate ligands were extensively described by Hoveyda in various catalytic transformations involving in situ generated catalysts ${ }^{17}$ while Jordan ${ }^{18}$ and Wang $^{19}$ reported on well-defined NHC-arenesulfonate metallacycles in polymerization reactions. NHC-alkylsulfonate ligands have also been reported, however the sulfonate functional group was used as a polar solvent (water, alcohol) solubilising tag. ${ }^{20}$

Figure 1 New ruthenium and iridium complexes

To the best of our knowledge, only one example of bidentate NHC-alkylsulfonate ligand was reported by Nozaki in $2009 .{ }^{21}$ In this article we report our results on the syntheses of ruthenium and iridium complexes bearing a NHC-methylenesulfonate ligand (Figure 1) and their use in alkylation of amines through hydrogen transfer processes and in alcohol etherification reaction. The synthesis of these three new complexes required the preliminary synthesis of the imidazolium salt 1 that proceeds via the synthesis of an imidazolium methylene halide salt such as 2 (Scheme 1). As outlined by several groups, this synthesis requires the utilization of expensive unsymmetrical $\mathrm{ICH}_{2} \mathrm{Cl}$ or $\mathrm{BrCH}_{2} \mathrm{Cl}$ in order to prevent the side formation of a bis-imidazolium salt. ${ }^{21,22}$ In order to decrease the cost of the ligand synthesis and because in our hands, the utilization of $I \mathrm{CH}_{2} \mathrm{Cl}$ did not prevent side products formation, we have developed a new synthetic pathway based on biphasic synthesis consisting in water and inexpensive dibromomethane. Indeed, we hypothesized that the halogenated imidazolium salt intermediate would readily migrate to the aqueous phase hence preventing bis-imidazolium side product formation. Thus, mesityl imidazole $\mathbf{3}$ was reacted with dibromethane in the presence of water for 16 hours. Analysis of the water layer highlighted the exclusive formation of the halogenated imidazolium salt 2 along with the protonated imidazole 4 arising from side dibromomethane decomposition. ${ }^{23}$ Addition of sodium sulphite acting both as nucleophile and base resulted in the clean formation of imidazolinium sulfonate zwitterion 1 along with bromomethylsulfonate side product. Extraction and recrystallization, cleanly afforded 1 in $30-40 \%$ reproducible isolated yields thus competing with previously described methods. It should be noted that the excess of dibromomethane could be easily recycled and reused by distillation. The zwitterionic structure was confirmed by X-ray crystallography (Scheme 1). According to Nozaki protocol, further preparation of the polymeric silver complex Ag-1 was successfully achieved for further transmetallation processes (Scheme 
2). With this silver complex in hand, we next investigated the coordination chemistry with various ruthenium and iridium metallic precursors (Scheme 2). Transmetallation of silver complex Ag-1 with 0.5 equivalent of the dimeric $\left[\mathrm{RuCl}_{2}(p \text {-cymene })\right]_{2}{ }^{24}$ in dichloromethane afforded the expected half-sandwich chiral ruthenium(II) complex Ru-1 in 85\% isolated yield. NMR analyses of the complex demonstrated the formation of sixmembered chelate by the presence of diastereotopic protons of the methylene bridge at 5.47 and $4.49 \mathrm{ppm}\left(J_{\mathrm{H}-}\right.$ $\mathrm{H}=13.0 \mathrm{~Hz}$ ). Analyses also demonstrated that the arene ligand remained bound to the ruthenium metallic centre highlighted by the presence of four distinct signals located at 5.75, 5.41, 5.24 and $3.30 \mathrm{ppm}$, respectively. It is noteworthy that these data are comparable to those reported by Albrecht and co-workers for the ruthenium complex Ru-3 analogue bearing a NHC-carboxylate chelate (Scheme 2). ${ }^{25}$

Scheme 1 Preparation of the zwiterrionic imidazolium sulfonate 1

Replacement of $\left[\mathrm{RuCl}_{2}(p \text {-cymene })\right]_{2}$ by $\left[\mathrm{Ru}(\mathrm{OAc})_{2}(p \text {-cymene })\right]^{26}$ was also successful and the corresponding arene ruthenium(II) complex Ru-2 featuring the chelate ligand 1 was obtained in $40 \%$ yield. This methodology is not limited to ruthenium metallic precursors and the reaction with $\left[\mathrm{Cp}^{*} \mid \mathrm{ICl}_{2}\right]_{2}$ cleanly afforded the corresponding three legs piano stool iridium(III) complex Ir-1. ${ }^{1} \mathrm{H}$ NMR analyses confirmed the formation of the six-membered chelate supported by the two doublet signals located at 5.18 and $4.73 \mathrm{ppm}$ in ${ }^{1} \mathrm{H}$ NMR.

Successful crystallization by solvent diffusion technique $\left(\mathrm{CH}_{2} \mathrm{Cl}_{2} / n\right.$-hexane) allowed the determination of the molecular structure of Ru-1 and Ir-1 which are represented in Figure 2. The six-membered $\{\mathrm{C}, \mathrm{O}\} \mathrm{Ru}$ chelate adopts a half-chair conformation and the molecular structure features a pseudotetrahedral environment at the ruthenium center. The structure of Ru-1 was compared with the previously reported carboxylate Ru- $\mathbf{3}^{25}$ and the phosphine-sulfonate analogs $\left[\mathrm{RuCl}\left(p\right.\right.$-cymene)(DPPBS)] Ru-4 ${ }^{27}$ (Scheme 2)(Table 1). The Ru-Cl bond (2.405(3)) is slightly shorter in Ru-1 than in the carboxylate analog (2.424(3)) but similar with the phosphine analog (2.3992(6)). Interestingly, the longer Ru-O bond lengths in Ru-1 and Ru-4 than in Ru-3 suggest lower stability of the resulting sulfonate chelates.

The leaving ability/slipping hapticity of the arene ligand have a crucial impact toward catalysis in the corresponding ruthenium complexes. ${ }^{28,29}$

Scheme 2 Preparation of the well-defined ruthenium and iridium complexes 
Thus, we next focused our attention on the reactivity of the well-defined Ru-1 complex toward arene displacement. As we previously reported, facile ligand exchange of arene ligand with acetonitrile occured in Ru4 at $90{ }^{\circ} \mathrm{C}^{12}$ However, similar reaction in boiling acetonitrile with Ru-1 did not lead to ligand exchange and surprisingly even after two days reaction time, the starting complex remained intact. Higher temperature, gave partial decomposition of the starting material and no noticeable effect of light irradiation was observed with this complex. This result is in line with the reported high thermal stability of Ru-3. ${ }^{25}$ It also tends to suggest that this stability of Ru-1 might impact in catalyses involving the loss of the arene ligand and thus would require higher reaction temperature. With this preliminary result in hand, we next focused our attention on the reactivity of the obtained well-defined complexes in hydrogen transfer reactions. Hydrogen autotransfers known as hydrogen borrowing or hydrogen shuttling have found interesting applications in synthesis for the preparation of various functionalized alcohols, amines and carbonyl derivatives. ${ }^{30}$ In order to avoid side effects (positive or negative) of external additives or solvent, we examined the activities of the prepared complexes in the base free $\mathrm{N}$-alkylation of amines with alcohols under solvent free reaction conditions (Table 2). Reaction of piperidine with benzyl alcohol at $130{ }^{\circ} \mathrm{C}$ under inert atmosphere of argon with a 100:1 substrate/catalyst ratio resulted in the formation of the $N$-benzylpiperidine ${ }^{31}$ and side product arising from our previously reported N,C-dialkylation. ${ }^{27}$ Good activity was obtained with Ru-1 and almost complete formation of 7aa was obtained in the presence of the iridium(III) precatalyst Ir-1 (Table 2, entry 1 and 2). However, a slight conversion decrease was observed with Ru-2 precatalyst (Table2, entry 3). Comparison with our previously reported precatalyst [IrCICp*(DPPBS)] highlighted that the use of Ir-1 led to a lower amount of the side dialkylated product 8aa, which decreased from a 80:20 to 97/3 ratio of 7aa/8aa (Table 2, entries 6, 9) whereas this reaction was minimized with other complexes. Taken together, these results suggest that the NHC-sulfonate chelate is more stable in Ir-1 than the corresponding [IrClCp*(DPPBS)]. Having established our best reaction conditions with Ir1 , we next investigated the scope of the transformation with various alcohols and amines (Scheme 4). Reaction with benzyl alcohol and various aliphatic secondary cyclic amines such as pyrrolidine, piperidine, morpholine and piperazine cleanly afford the corresponding tertiary amines in up to $90 \%$ isolated yield after column chromatography over alumina gel.

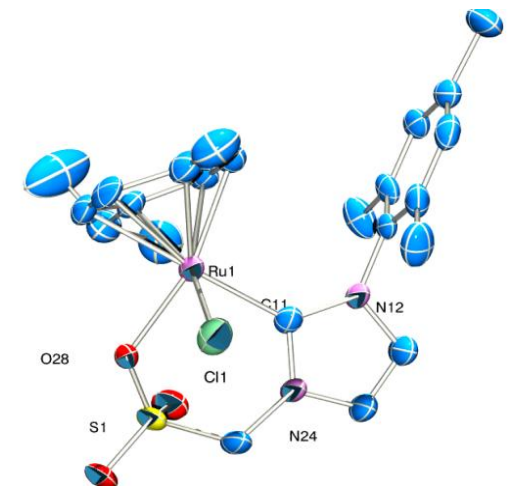

Ru-1

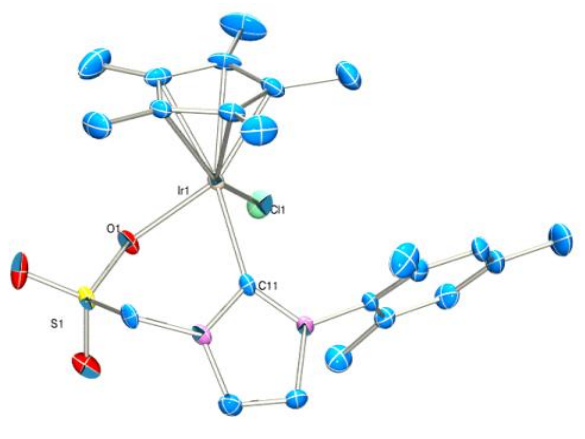

Ir-1

Figure 2 Structure of pure complexes Ru-1, $0.5 \mathrm{CH}_{2} \mathrm{Cl}_{2}$ and Ir-1, $1 \mathrm{CH}_{2} \mathrm{Cl}_{2}$. Thermal ellipsoids are drawn at the $50 \%$ probability level. Hydrogen atoms and solvents are omitted for clarity. 
Table 1 Selected bond lengths and angles of prepared complexes, comparison with reported complexes

\begin{tabular}{ccccc}
\hline & Ru-1 & $\begin{array}{c}\text { Ru-3 ref. } \\
25\end{array}$ & $\begin{array}{c}\text { Ru-4 ref. } \\
27\end{array}$ & Ir-1 \\
\hline $\mathrm{M}-\mathrm{Cl}$ & $2.405(3)$ & $2.424(3)$ & $2.3992(6)$ & $2.374(1)$ \\
$\mathrm{M}-\mathrm{O}$ & $2.157(5)$ & $2.079(8)$ & $2.118(1)$ & $2.227(3)$ \\
$\mathrm{M}-\mathrm{C}_{\text {centroid }}$ & 1.685 & 1.701 & 1.693 & 1.806 \\
$\mathrm{M}-\mathrm{C}_{\mathrm{NHC}}(\mathrm{P})$ & $2.088(8)$ & $2.033(9)$ & $2.3570(8)$ & $2.058(5)$ \\
$\mathrm{Cl}-\mathrm{M}-\mathrm{C}_{\mathrm{NHC}}(\mathrm{P})$ & $83.2(2)$ & $83.5(3)$ & 85.9 & $89.85(10)$ \\
$\mathrm{O}-\mathrm{M}-\mathrm{C}_{\mathrm{NHC}}(\mathrm{P})$ & $88.7(3)$ & $86.7(3)$ & 90.7 & $83.27(12)$ \\
$\mathrm{O}-\mathrm{M}-\mathrm{Cl}$ & $88.12(16)$ & $88.5(2)$ & 80.9 & $82.31(8)$ \\
\hline
\end{tabular}

The use of aniline resulted in lower conversion giving 7 ea in $64 \%$ yield and confirmed the influence of amine basicity toward conversion. The use of aliphatic alcohol such as hexanol was also compatible with the optimized reaction conditions to afford the amines $\mathbf{7 a b}, \mathbf{7 b b}, \mathbf{7 d b}$ and $\mathbf{7 e b}$ in $56-85 \%$ range isolated yield. Finally, secondary alcohol such as phenylethanol led to the corresponding racemic amines 7bc, 7ac, 7cc in moderate isolated yields.

Scheme 3 Arene ligand exchange

Table $2 \mathrm{~N}$-Alkylation of piperidine $5 \mathrm{a}$ with benzyl alcohol $6 \mathrm{a}^{a}$

\begin{tabular}{cccccc}
\hline entry & Cat. & $\mathrm{T}\left({ }^{\circ} \mathrm{C}\right)$ & $\begin{array}{c}\text { Ratio } \\
\text { 7aa/8aa }\end{array}$ & $\begin{array}{c}\text { conv. } \\
(\%)^{b}\end{array}$ & $\begin{array}{c}\text { Yield of } \\
\mathbf{7}^{b}\end{array}$ \\
\hline 1 & Ir-1 & 130 & $99: 1$ & 100 & $99(85)$ \\
2 & $\mathbf{R u - 1}$ & 130 & $98: 2$ & 93 & 91 \\
3 & $\mathbf{R u - 2}$ & 130 & $96: 4$ & 76 & 73 \\
4 & $\mathbf{R u - 4}$ & 130 & $97: 3$ & 100 & 96
\end{tabular}




\begin{tabular}{|c|c|c|c|c|c|}
\hline 5 & [IrClCp*(DPPBS)] & 130 & $95: 5$ & 99 & 94 \\
\hline 6 & Ir-1 & 150 & $97: 3$ & 100 & 96 \\
\hline 7 & Ru-1 & 150 & $88: 12$ & 91 & 80 \\
\hline 8 & Ru-4 & 150 & $94: 6$ & 99 & 92 \\
\hline 9 & {$[\mid \mathrm{IClCp} *(\mathrm{DPPBS})]$} & 150 & $80: 20$ & 99 & 79 \\
\hline \multicolumn{6}{|c|}{$\begin{array}{l}{ }^{a} \text { Experimental conditions : all reactions were performed under an inert } \\
\text { atmosphere of argon and carried out with } 5 \mathrm{a} / 6 \mathrm{6} / \text { precatalyst in } \\
1 / 1.2 / 0.01 \text { molar ratio at indicated temperature. }{ }^{b} \text { conversion and yield } \\
\text { were determined by GC analysis and the number in parenthesis } \\
\text { corresponds to the isolated yield after purification by column } \\
\text { chromatography }\end{array}$} \\
\hline
\end{tabular}

The catalytic activity of complexes Ru-1 and Ir-1 was next evaluated in the direct $\beta$-alkylation of tertiary cyclic amines with benzaldehyde through in situ generation of the corresponding enamine (Table 3). ${ }^{10 a}$ As we previously reported, $\beta$-alkylation of $N$-phenylpiperidine $9 a$ is difficult in regard to the direct endo dehydrogenation. As result the use of catalytic amount of Ru-1 at $150{ }^{\circ} \mathrm{C}$ only provided $18 \%$ of the corresponding amine 11a after complete reduction of the resulting alkylated enamine derivatives (Table 3, entry 1). Surprisingly, the use of precatalyst Ir-1 also afforded poor yield of 11a (Table 3, entry 2). In contrast reaction with our previously reported $\left[\mathrm{IrClCp}^{*}\right.$ (DPPBS)] gave $93 \%$ of the expected $\beta$-alkylated amine 11a (Table3, entry 3). The activities of Ru-1 and Ir-1 were not restored with the use of $N$-methylpiperidine and decomposition of $\mathbf{9 b}$ mainly occurred yielding a maximum $18 \%$ yield with Ru-1 (entry 4). These results confirmed the higher stability of the new $\left(\boldsymbol{K}^{2} \mathbf{C}, \mathbf{0}\right)$ chelate complexes. 


\begin{tabular}{|c|c|c|c|c|}
\hline entry & Cat. & 9 & conv. $^{b}$ & $\begin{array}{c}\text { Yield of } \\
\mathbf{1 1}^{b}\end{array}$ \\
\hline 1 & Ru-1 & $9 a$ & 20 & 18 \\
\hline 2 & Ir-1 & $9 a$ & 20 & 16 \\
\hline 3 & [IrClCp*(DPPBS)] & $9 a$ & 94 & 93 \\
\hline 4 & Ru-1 & $9 b$ & 100 & 18 \\
\hline 5 & Ir-1 & $9 b$ & 100 & 14 \\
\hline \multicolumn{5}{|c|}{$\begin{array}{l}{ }^{a} \text { Experimental conditions : all reactions were performed } \\
\text { under an inert atmosphere of argon and carried out with } \\
9 / 10 / \mathrm{HCO}_{2} \mathrm{H} / \text { precatalyst in } 1 / 1.2 / 1.5 / 0.01 \text { molar ratio at } \\
150^{\circ} \mathrm{C} .{ }^{b} \text { conversion and yield were determined by GC } \\
\text { analysis. }\end{array}$} \\
\hline
\end{tabular}

Given the electronic properties of the sulfonate ligand which acts as a strong electron withdrawing ligand hence increasing the overall electrophilicity of the metal centre of the resulting complexes, ${ }^{7}$ we next examined the relative electrophilicity of our synthesized complexes in the absence of organic bases such as amine. As depicted in Scheme 5, when the rac-phenylethanol was heated in the presence of Ru-1, selective etherification occurred affording the rac/meso ether 12 in $45 \%$ isolated yield along with traces of styrene whereas in the presence of Ir-1 the alcohol 6 remained unreacted. ${ }^{32}$ Noteworthy that no $\beta$-alkylation occurred on $6 c$ in the absence of base to give the corresponding dimeric alcohols. ${ }^{33}$

Scheme 5 Etherification of phenylethanol 6c

\section{Conclusions}

We have reported the straightforward synthesis of an imidazolium-sulfonate NHC precursor from symmetrical dibromomethane allowing the preparation of the corresponding well-defined ruthenium and iridium complexes. Preliminary investigation in catalysis highlighted its high thermal stability. Future efforts will be devoted to the use of more labile arene ligand to facilitate catalysis as well as the application to other catalytic transformations involving cooperative mechanisms. Considering the facile preparation of the bromomethylimidazolium, it might also open new insights for the preparation of diverse heterotopic prochelates and mixed bis-NHCs.

\section{Ackowledgements:}

The authors thank Dr. Thierry Roisnel and Dr. Vincent Dorcet for X-Ray analyses. F.H. thanks the ANR (MemChem project) for funding. A.R.S. thanks the CEFIPRA/IFCPAR (IFC/A/5105-4/2014 1777) for PhD fellowship. 


\section{Notes and references}

$\S$ These authors contributed equally to this work.

1 R. Noyori and S. Hashigishi, Acc. Chem. Res., 1994, 30, 97, 35, 3523; T. Ikariya, K. Murata and R. Noyori, Org. Biomol. Chem., 2006, 4, 393.

2 S. H. Chikkali, J. I. van der Vlugt and J. N. H. Reek, Coord. Chem. Rev., 2014, 262, 1.

3 A. K. Shiryaev, Curr. Org. Chem., 2012, 16, 1788.

4 Z. Freixa and P. W. N. M. van Leeuwen, Coord. Chem. Rev., 2008, 252, 1755.

5 (a) G. van Koten, J. Organomet. Chem., 2013, 730, 156; (b) C. Gunanathan and D. Milstein, Chem. Rev., 2014, 114, 12024.

6 Reviews : (a) A. Nakamura, S. Ito and K. Nozaki, Chem. Rev., 2009, 109, 5215; (b)A. Nakamura, T. M. J. Anselment, J. Claverie, B. Goodall, R. F. Jordan, S. Mecking, B. Rieger, A. Sen, P. W. N. M. van Leeuwen and K. Nozaki, Acc. Chem. Res., 2013, 46, 1438; (c) F. Jiang, M. Achard and C. Bruneau, Synthesis and Applications in Catalysis of Metal Complexes with Chelating Phosphinosulfonate Ligands. In Advances in Organometallic Chemistry; Perez, P. J., Ed.; Academic Press: Burlington, 2014; 62, pp 159.

7 Selected references : (a) E. Drent, R. van Dijk, R. van Ginkel, B. van Oort and R. I. Pugh, Chem. Commun., 2002, 744; (b) W. Weng, Z. Shen and R. F. Jordan, J. Am. Chem. Soc., 2007, 129, 15450; (c) L. Betucci, C. Bianchini, C. Claver, E. J. Garciá Suárez, A. Ruiz, A. Meli and W. Oberhauser, Dalton Trans., 2007, 5590; (d) T. Kochi, S. Noda, K. Yoshimura and K. Nosaki, J. Am. Chem. Soc., 2007, 129, 8948; (e) A. Nakamura, T. Kageyama, H. Goto, B. P. Carrow, S. Ito and K. Nozaki, J. Am. Chem. Soc., 2012, 134, 12366; (f) T. Rünzi, D. Frölich and S. Mecking, J. Am. Chem. Soc., 2010, 132, 17690; (g) T. M. J. Anselment, C. Wichmann, C. E. Anderson, E. Herdtweck and B. Rieger, Organometallics, 2011, 30, 6602; (h) L. Piche, J.-C. Daigle and J. P. Claverie, Chem. Eur. J. 2012, 18, 3277; (i) B. Neuwald, L. Caporaso, L. Cavallo and S. Mecking, J. Am. Chem. Soc., 2013, 135, 1026; (j) J. -C. Daigle, A. A. Arnold, L. Piche and J. P. Claverie, Polym. Chem., 2013, 4, 449

8 (a) B. Sundararaju, M. Achard, B. Demerseman, L. Toupet, G. V. M. Sharma and C. Bruneau, Angew. Chem. Int. Ed., 2010, 49, 2782; (b) A. Dupé, M. Achard, C. Fischmeister, C. Bruneau, ChemSusChem, 2012, 5, 2249.

9 (a) K. Yuan, F. Jiang, Z. Sahli, M. Achard and C. Bruneau, Angew. Chem. Int. Ed., 2012, 51 8876; (b) Z. Sahli, B. Sundararaju, M. Achard and C. Bruneau, Green Chem., 2013, 15, 775; (c) A. Labed, F. Jiang, I. Labed, A. Lator, M. Peters, M. Achard, A. Kabouche, Z. Kabouche, G. V. M. Sharma and C. Bruneau, ChemCatChem, 2015, 7, 1090; (d) F. Jiang, M. Achard and C. Bruneau, Chem. Eur. J., 2015, accepted.

10 I. Labed, A. Labed, Y. Sun, F. Jiang, M. Achard, S. Dérien, Z. Kabouche and C. Bruneau, Catal. Sci. Technol., 2015, 5, 1650.

11 F. Jiang, M. Achard and C. Bruneau, Chem. Eur. J., 2013, 19, 10343.

12 F. Jiang 2014, New ruthenium and iridium catalysts for transformations involving hydrogen transfers, Rennes 1 University, Rennes.

13 (a) W. A. Herrmann, Angew. Chem. Int. Ed., 2002, 41, 1290; (b) E. A. B Kantchev, C. J. O'Brien and M. G. Organ, Angew. Chem. Int. Ed., 2007, 46, 2768; (c) C. Samojlovic, M. Bieniek and K. Grela, Chem. Rev., 2009, 109, 3708.

14 (a) E. Peris and R. H. Crabtree, Coord. Chem. Rev., 2004, 248, 2239; (b) J. A. Mata, M. Poyatos and E. Peris, Coord. Chem. Rev., 2007, 251, 841; (c) T. Yagyu, A. Tsubouchi and Y. Nishimura, J. Organomet. Chem., 2014, 767, 1; (d) S. N. Sluijter, S. Warsink, M. Lutz and C. J. Elsevier, Dalton Trans., 2013, 42, 7365.

15 V. César, S. Bellemin-Laponnaz and L. H. Gade, Chem. Soc. Rev., 2004, 33, 619.

16 K. Endo and R. H. Grubbs, J. Am. Chem. Soc., 2011, 133, 8528.

17 F. Gao, J. L. Carr and A. H. Hoveyda, J. Am. Chem. Soc., 2014, 136, 2149 and references therein.

18 X. Zhou and R. F. Jordan, Organometallics, 2011, 30, 4632.

19 (a) M. Li, H. Song and B. Wang, Organometallics, 2015, 34, 1969; (b) M. Li, H. Song and B. Wang, Eur. J. Inorg. Chem., 2015, 4055.

20 (a) J. R. Moore, S. M. Cooks, M. S. Anderson, H.-J. Schanz, S. T. Griffin, R. D. Rogers, M. C. Kirk and K. H. Shaughnessy, Organometallics, 2006, 25, 5151; (b) A. Almassy, C. E. Nagy, A. C. Benyei and F. Joo, Organometallics, 2010, 29, 2484; (c) R. Zhong, A. Pöthig, Y. Feng, K. Riener, W. A. Herrmann and F. E. Kuhn, Green Chem., 2014, 16, 4955; (d) K. Li, T. Zou, Y. Chen, X. Guan and C.-M. Che, Chem. Eur. J., 2015, 21, 7441; (e) A. Azua, S. Sanz and E. Peris, Organometallics, 2010, 29, 3661; (f) A. Azua, J. A. Mata, P. Heymes, E. Peris, F. Lamaty, J. Martinez and E. Colacino, Adv. Synth. Catal., 2013, 355, 1107. (g) A. Azua, S. Sanz and E. Peris, Chem. Eur. J., 2011, 17, 3963.

21 Y. Nagai, T. Kochi and K. Nozaki, Organometallics, 2009, 28, 6131.

22 N. Yang, Y. Yuan, R. Dykeman, Y. Kou and P. J. Dyson, Angew. Chem. Int. Ed., 2010, 49, 5549.

23 M. G. Gardiner, C. C. Ho, F. M. Mackay, D. S. McGuiness and M. Tucker, Dalton Trans., 2013, 42, 7447.

24 For a recent update on arene ruthenium complexes see : G. Süss-Fink, J. Organomet. Chem., 2014, 751, 2.

25 C. Gandolfi, M. Heckenroth, A. Neels, G. Laurenczy and M. Albrecht, Organometallics, 2009, 28, 5112.

26 D. A. Tocher, R. O. Gloud, T. A. Stephenson, M. A. Bennett, J. P. Ennett, T. W. Matheson, L. Sawyer and V. K. Shah, J. Chem. Soc. Dalton Trans., 1983, 1571.

27 B. Sundararaju, Z. Tang, M. Achard, G. V. M. Sharma, L. Toupet and C. Bruneau, Adv. Synth. Catal. 2010, $352,3141$.

28 (a) S. Ogo, T. Abura and Y. Watanabe, Organometallics, 2002, 21, 2964; (b) K. Everaere, A. Mortreux and J.-F. Carpentier, Adv. Synth. Catal., 2003, 345, 67; (c) C. Daguenet, R. Scopelliti and P. J. Dyson, Organometallics, 2004, 23, 4849.

29 S. Fernandez, M. Pfeffer, V. Ritleng and C. Sirlin, Organometallics, 1999, 18, 2390.

30 (a) S. Bähn, S. Imm, L. Neubert, M. Zhang, H. Neumann and M. Beller, ChemCatChem, 2011, 3, 1853; (b) J. Moran and M. J. Krische, Pure Appl Chem., 2012, 84, 1729; (c) C. Gunanathan and D. Milstein, Science, 2013, 341, 249; (d) Q. Yang, Q. Wang and Z. Yu, Chem. Soc. Rev., 2015, 44, 2305. 
31 M. H. S. A. Hamid, C. L. Allen, G. W. Lamb, A. C. Maxwell, H. C. Maytum, A. J. A. Watson and J. M. J. Williams, J. Am. Chem. Soc., 2009, 131, 1766.

32 J. Kim, D.-H Lee, N. Kalutharage and C. S. Yi, ACS Catal.,2014, 4, 3881.

33 K. Taguchi, H. Nakagawa, T. Hirabayashi, S. Sakaguchi and Y. Ishii, J. Am. Chem. Soc., 2004, 126, 72. 